\title{
Effect of certain agronomic practices for the management of wilt of pigeonpea in Manipur agro-climatic conditions.
}

\author{
T. Ranjana Devi ${ }^{1}$, GKN Chhetry ${ }^{2}$ \\ ${ }^{1,2}$ (Department of Life Sciences, Manipur University, Canchipur, 795003)
}

\begin{abstract}
Field experiments were conducted during 2009-10 and 2010-11 in rainfed conditions on sandy soil to ascertain the effect of various agronomic practices such as application of farm yard manure (FYM), poultry manure (PM), mixture of FYM and PM (FYM+PM), soil solarization and intercropping (pigeonpea: maize) on wilt of two local varieties of pigeonpea (V1: early maturing variety and V2: late maturing variety). Among the different treatments soil solarization was more effective in controlling wilt disease of pigeonpea to the extent of (37.21\%) in early maturing variety (V1) and (44.37\%) in late maturing variety (V2) as compared to other treatments.
\end{abstract}

Keywords: FYM, Intercropping, PM, Soil solarization, wilt

\section{INTRODUCTION}

Pigeonpea (Cajanus cajan L. Millsp.) is a grain legume crop. It is cultivated mostly in the hills of Manipur for pulse (dal) under fallow jhumland, dry sloppy land and terraced land in organic mode. It finds an important place in the farming system adopted by small and marginal farmers as it restores the soil fertility by fixing atmospheric nitrogen. Wilt disease caused by Fusarium udum Butler is a major biotic yield constraint of this crop. Organic amendment and intercropping with other crop is a common practice adopted by the farmers as they are not willing to accept the synthetic chemical fertilizers for its hazardous effect. Organic amendments are recommended as biological means to reduce the incidence of several soil-borne plant pathogens. Intercropping especially a cereal-legume combination, have the potential to achieve grain yield and greater land use efficiency than sole cropping [1]. The objective of the present study is to evaluate the effect of different agronomic practices adopted by the farmers and soil solarization on wilt disease of pigeonpea.

\section{MATERIALS AND METHODS}

Field trials were conducted during kharif seasons ( 2009-2010) at wilt sick farmer's field located at Chirang $16 \mathrm{Km}$ away from Imphal $\left(24.30^{\circ} \mathrm{N}\right.$ and $25.00^{\circ} \mathrm{N}$ latitudes and $93.45^{\circ} \mathrm{E}$ and $94.15^{\circ} \mathrm{E}$ longitudes) on two local varieties (landraces) of pigeonpea viz. early maturing varietiy (V1) and late maturing variety (V2). The treatments comprised of agronomic practices such as farm yard manure (FYM) $5 @ \mathrm{t} \mathrm{ha}^{-1}$, poultry manure (PM) $@ 1.5 \mathrm{t} \mathrm{ha}^{-1}, \mathrm{FYM}+\mathrm{PM}(2: 1)$, soil solarization and intercropping. The organic manures were amended into the well prepared field two weeks before sowing. Soil solarization was done during the hottest summer month (May i.e., $\mathrm{T}=35^{\circ} \mathrm{c}$ ) using transparent polythene sheets (400 gauge) for 45 days [2]. Soil was placed around the edges of each polythene sheet in such a way that there was no air gap. The polythene sheets were removed after completion of $45^{\text {th }}$ days of solarization. For intercropping, 2 rows of pigeonpea were alternated with one row of maize. One plot without any treatment was taken as control plot in three replications.

The experiment was laid out in randomized block design with three replications following the standard technique suggested by ICRISAT. Plot size of $\left(2 \times 2 \mathrm{~m}^{2}\right)$ was prepared. Seeds were sown by dibbling method spaced $30 \mathrm{~cm}$ within rows. Thinning was done ten days after planting. All plots were hand weeded twice (at $3^{\text {rd }}$ and $7^{\text {th }}$ weeks after planting). For disease assessment the percent disease incidence was calculated by dividing the total number of plants infected by the disease by total number of plants observed multiplied by 100 . Disease severity was measured using the severity rating adopted on 9 point scale [3] . Readings were taken after the incidence of wilt at monthly interval. The variances among the treatments were tested using two ways ANOVA and $t$ test.

\section{RESULTS AND DISCUSSIONS}

The incidence and severity of wilt disease was reduced to some extent in the organic manure amended soil as compared to non amended soils (tables1 and 2). Among the organic amendments maximum disease control $22.59 \%$ in early maturing variety of pigeonpea and $33.51 \%$ in late maturing variety of pigeonpea were recorded. Statistically, there were no significant effect between the treatments in controlling wilt disease of both varieties of pigeonpea. Earlier workers have reported enhanced control of cumin wilt caused by Fusarium oxysporum f.sp. cumini by bioagents in presence of FYM amended soils [4]. The suppression of pigeonpea wilt pathogen exposed three weeks after margosa-cake amended soil was also observed [5]. Some workers also 
reported the effectiveness of neem leaves amended soil in reducing Fusarium udum population[6]. It is well known fact that the decomposition of the organic matter helped in alternation of the physical, chemical and biotic conditions of the soil. Soil solarized plots showed maximum disease control $(37.21 \%)$ in early maturing variety and (44.37\%) in late maturing variety (table 3) [6]. The absence of Fusarium colonies was observed on PDA petriplates after 45 days of solarization. [2] .also observed reduction of wilt incidence in solarized plot of pigeonpea under both irrigated and non-irrigated conditions.Population of Fusarium udum, Fusarium oxysporum f.sp.ciceri significantly reduced at $5 \mathrm{~cm}$ depth followed by $10 \mathrm{~cm}$ and $15 \mathrm{~cm}$ with increase in temperature and length of days of solarization[7]. The effectiveness of soil solarization in controlling wilt disease over control was due to increase in soil temperature $\left(45^{\circ} \mathrm{c}\right)$ below the polythene sheet.This increase in soil temperature with solarization has been considered as the major driving force for the various biological and physiological changes in the soil that affect plant growth [8]. Pigeonpea:maize intercropping showed less significant effect $(19.34 \%)$ in early maturing variety and $(27.65 \%)$ in late maturing variety (table 4$)$. Pigeonpea intercropped with maize in wilt sick plot is less effective in reducing wilt incidence which is in accordance with [9]. However pigeonpea intercropped with sorghum is effective in suppressing Fusarium udum population and reduction of wilt disease [10].Thus, there is a need to investigate the integrated effect of certain agronomic practices on F.udum population for effective management of the disease

\section{TABLeS}

Table1. Effect of organic amendments on wilt disease of early maturing variety of pigeonpea (V1).

\begin{tabular}{|c|c|c|c|c|c|c|c|}
\hline \multirow[t]{2}{*}{ Treatments } & \multicolumn{2}{|c|}{${ }^{*}$ Disease incidence $(\%)$} & \multirow[t]{2}{*}{ Mean } & \multicolumn{2}{|c|}{${ }^{*}$ Disease severity $(\%)$} & \multirow[t]{2}{*}{ Mean } & \multirow{2}{*}{$\begin{array}{l}\% \\
\text { Disease } \\
\text { control }\end{array}$} \\
\hline & 2009 & 2010 & & 2009 & 2010 & & \\
\hline FYM & 68.33 & 80.07 & 74.2 & 64.5 & 78.58 & 71.54 & 22.59 \\
\hline PM & 70.75 & 81.59 & 76.17 & 66.86 & 79.18 & 73.02 & 20.53 \\
\hline FYM+PM & 74.97 & 84.2 & 79.58 & 72.46 & 80.52 & 76.49 & 16.97 \\
\hline Control & 94.7 & 97.2 & 95.85 & 92.84 & 96.98 & 94.91 & \\
\hline $\mathrm{CD} @ 5 \%$ & 15.17 & & & 15.74 & & & \\
\hline
\end{tabular}

Table2. Effect of organic amendments on wilt disease of late maturing variety of pigeonpea (V2).

\begin{tabular}{|c|c|c|c|c|c|c|c|}
\hline \multirow[t]{2}{*}{ Treatments } & \multicolumn{2}{|c|}{${ }^{\star}$ Disease incidence $(\%)$} & \multirow[t]{2}{*}{ Mean } & \multicolumn{2}{|c|}{ *Disease severity $(\%)$} & \multirow[t]{2}{*}{ Mean } & \multirow{2}{*}{$\begin{array}{l}\% \\
\text { Disease } \\
\text { control }\end{array}$} \\
\hline & 2009 & 2010 & & 2009 & 2010 & & \\
\hline FYM & 64.3 & 62.94 & 63.62 & 60.76 & 59.69 & 60.22 & 33.51 \\
\hline PM & 64.45 & 70.86 & 67.66 & 64.45 & 66.46 & 65.46 & 29.29 \\
\hline FYM+PM & 70.21 & 70.32 & 70.26 & 66.33 & 67.7 & 67.02 & 26.57 \\
\hline Control & 93.76 & 97.61 & 95.69 & 92.41 & 96.37 & 94.39 & \\
\hline $\mathrm{CD} @ 5 \%$ & 19.52 & & & 19.56 & & & \\
\hline
\end{tabular}

*average value of disease incidence and severity

Table 3.Effect of soil solarization on wilt disease of pigeonpea.

\begin{tabular}{|c|c|c|c|c|c|c|c|c|c|c|c|c|c|c|}
\hline \multirow[t]{4}{*}{ Treatment } & \multicolumn{12}{|c|}{ Disease parameters } & \multirow{2}{*}{\multicolumn{2}{|c|}{$\begin{array}{l}\% \text { disease } \\
\text { control }\end{array}$}} \\
\hline & $\mathrm{DI}(\%)$ & & mean & $\mathrm{DI}(\%)$ & & mean & $\mathrm{DS}(\%)$ & & mean & $\mathrm{DS}(\%)$ & & mean & & \\
\hline & V1 & & & $\mathrm{V} 2$ & & & V1 & & & $\mathrm{V} 2$ & & & V1 & $\mathrm{V} 2$ \\
\hline & 09 & 10 & & $\begin{array}{l}09 . \\
10\end{array}$ & $10-11$ & & 09 & 10 & & $\begin{array}{l}09- \\
10\end{array}$ & $\begin{array}{l}10 . \\
11\end{array}$ & & & \\
\hline $\begin{array}{l}\text { Soil } \\
\text { solarizatio }\end{array}$ & 60.15 & 60.22 & 60.18 & 52.0 & 54.46 & 44.37 & 55.98 & 56.08 & 56.03 & 47.59 & 50.04 & 48.82 & 37.21 & 44.37 \\
\hline control & 94.7 & 97.2 & 95.85 & 93.76 & 97.61 & 95.69 & 92.84 & 96.98 & 94.91 & 92.41 & 96.37 & 94.39 & & \\
\hline t value & $* 6.43$ & & & $* 9.41$ & & & $* 6.23$ & & & $* 10.32$ & & & & \\
\hline
\end{tabular}

V1:early maturing variety; V2:late maturing variety * significant at $p<5 \%$ 
Table 4.Effect of pigeonpea:maize intercropping on wilt disease of pigeonpea.

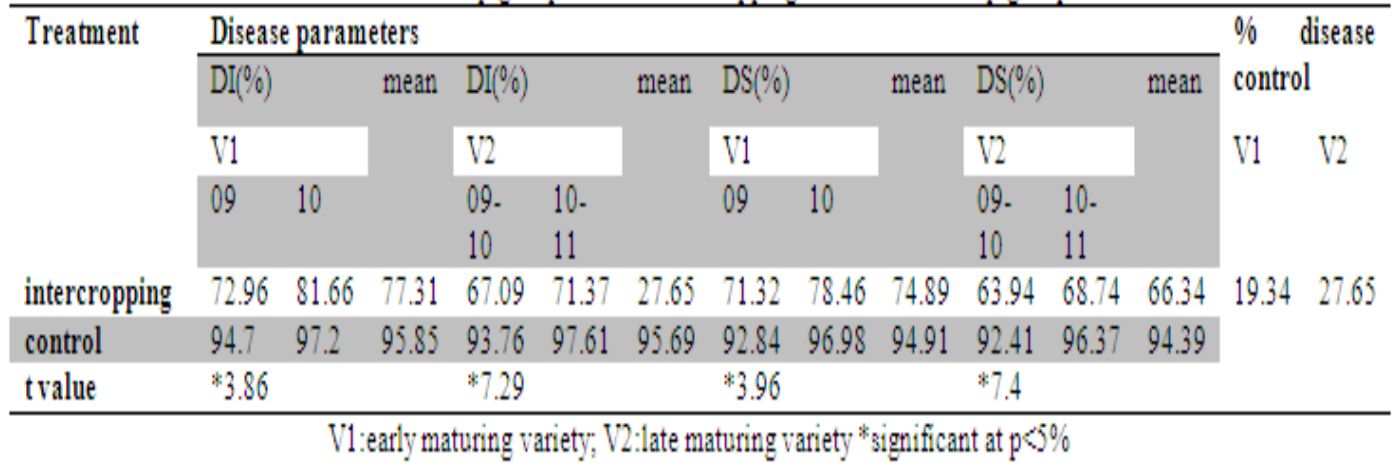

\section{CONCLUSION}

Based on the experiment conducted for two years, it could be concluded that the traditional practice of using soil amendments is found to be less effective against wilt disease of pigeonpea caused by Fusarium udum Butler a soil borne pathogen. However, soil solarization of pigeonpea field is more effective in suppressing the disease. This could be utilized in the ecofriendly management of the disease in Manipur agroclimatic condition. Further research is needed to explore the importance of soil solarization on traditional farming practices and application of this technology on a large scale.

\section{REFERENCES}

[1]. P.K.Ghosh, P.Ramesh, K.K. Bandyopadhyay, A.K. Tripathi, K.M. Hati , A.K. Misra, C.L. Acharya, Comparative effectiveness of cattle manure, poultry manure, phosphocompost and fertilizer-NPK on three cropping systems in vertisols of semi-arid tropics.I, Crop yields and system performance, Bioresource Technology, 95, 2004, 77-83.

[2]. Y.S.Chauhan, Y.L. Nene, C. Johansen ,M.P. Haware, N.P. Saxena, Sardar Singh, S.B.Sharma, K.L. Sahawat, J.R. Burford, O.P. Rupela, J.V.D.K. Kumar Rao, and S. Sithanantham, Effect of soli solarization on pigeonpea and chickpea. Research Bulletin No. 11, International Crop Research Institute for the semi-arid tropics, Patancheru, A.P. 502304, India, 1998,1-2.

[3]. C.D. Mayee and V.V. Datar , Phytopathometry (Ed. C.D. Mayee and V.V. Datar, Marathwada Agricultural University, Parbhani, Maharastra,1986) 63-64.

[4]. Nitin Chawla, S.Gangopadhyay, Integration of organic amendments and bioagents in suppressing cumin wilt caused by Fusarium oxysporum f. sp. cumini. Indian Phytopath, 62 (2), 2009, 209-216.

[5]. Narendra Singh and R.S. Singh, Effect of oil-cake amended soil atmosphere on pigeonpea wilt pathogen, Indian Phytopath., 35(2), 1982 , 300-305.

[6]. D.S. Mathew, Studies on rhizosphere microflora of pigeonpea: qualitative and quantitative incidence of microorganisms after solarization, Indian Phytopath., 46 (2), 1993, 151-154.

[7]. Ankita Shukla, S.K.Dwivedi, Implication of solarization against soil-borne Fusaria in leguminous crop fields in Kalli paschim village in Lucknow,India : A tropical country,International Journal of Environmental Sciences, 2(2), $2011,1083-1092.6]$ Arun Arya,

[8]. J.Katan , Solar heating (solarization) of the soil for control of soil borne pests. Annual Review of Phytopathology, 19, 1981, 211-236.

[9]. S.S. Madhukeshwara, B.C.Shankaralingappa, S.G. Mantur and T.B. Anil Kumar, Effect of intercrops and fertility levels on wilt incidence of pigeonpea, Indian Phytopath., 56(1), 2003, 88-90.

[10]. M.K.Naik,M.V.Reddy, T.N. Raju, D. McDonald, Wilt disease in sole and sorghum intercropped pigeonpea at different inoculum densities of Fusarium udum, Indian Phytopath., 50 (3), 1997, 337-341. 